\title{
The importance of combined NGS and MLPA genetic tests for differential diagnosis of maturity onset diabetes of the young
}

\author{
Znaczenie skojarzonych badań genetycznych metodami NGS i MLPA \\ w diagnostyce różnicowej cukrzycy MODY
}

\author{
Jovana Komazec ${ }^{1}$, Vera Zdravkovic ${ }^{2}$, Silvija Sajic ${ }^{2}$, Maja Jesic ${ }^{2}$, Marina Andjelkovic ${ }^{1}$, Sonja Pavlovic ${ }^{1}$, \\ Milena Ugrin ${ }^{1}$ \\ ${ }^{1}$ Institute of Molecular Genetics and Genetic Engineering, Belgrade, Serbia and Montenegro \\ ${ }^{2}$ Division of Endocrinology, University Children's Hospital, Belgrade, Serbia and Montenegro; School of Medicine, \\ University of Belgrade, Belgrade, Serbia and Montenegro
}

\begin{abstract}
Introduction: Maturity onset diabetes of the young (MODY) is a rare form of monogenic diabetes. Being clinically and genetically heterogeneous, it is often misdiagnosed as type 1 or type 2 diabetes, leading to inappropriate therapy. MODY is caused by a single gene mutation. Thirteen genes, defining 13 subtypes, have been identified to cause MODY. A correct diagnosis is important for the right therapy, prognosis, and genetic counselling.

Material and methods: Twenty-nine unrelated paediatric patients clinically suspected of having MODY diabetes were analysed using TruSight One panel for next-generation sequencing (NGS) and multiplex ligation-dependent probe amplification (MLPA) assay.

Results: In this study we identified variants in MODY genes in 22 out of 29 patients (75.9\%). Using two genetic tests, NGS and MLPA, we detected both single nucleotide variants and large deletions in patients. Most of the patients harboured a variant in the GCK gene (11/22), followed by HNF1B (5/22). The rest of the variants were found in the NEUROD1 and HNF1A genes. We identified one novel variant in the GCK gene: c.596T >C, p.Val199Ala. The applied genetic tests excluded the suspected diagnosis of MODY in two patients and revealed variants in other genes possibly associated with the patient's clinical phenotype.

Conclusions: In our group of MODY patients most variants were found in the GCK gene, followed by variants in HNF1B, NEUROD1, and HNF1A genes. The combined NGS and MLPA-based genetic tests presented a comprehensive approach for analysing patients with suspected MODY diabetes and provided a successful differential diagnosis of MODY subtypes. (Endokrynol Pol 2019; 70 (1): 28-36)
\end{abstract}

Key words: MODY; NGS; MLPA, differential diagnosis

\section{Streszczenie}

Wstęp: Cukrzyca MODY to rzadka forma cukrzycy monogenowej. Z uwagi na jej zróżnicowanie kliniczne i genetyczne często jest błędnie diagnozowana jako cukrzyca typu 1 lub 2, co prowadzi do zastosowania niewłaściwego leczenia. Cukrzyca MODY jest spowodowana mutacją pojedynczego genu. Zidentyfikowano 13 genów, których mutacje powodują 13 podtypów cukrzycy MODY. Postawienie prawidłowej diagnozy jest ważne, ponieważ umożliwia zastosowanie właściwego leczenia, określenie rokowania i poradnictwo genetyczne. Materiał i metody: Używając panelu genów TruSight One do sekwencjonowania nowej generacji (NGS) i zależnej od ligacji multipleksowej amplifikacji sond (MLPA), zbadano 29 niespokrewnionych pacjentów pediatrycznych z podejrzeniem klinicznym cukrzycy MODY. Wyniki: Warianty genów związanych z cukrzycą MODY zidentyfikowano u 22 spośród 29 chorych (75,9\%). Za pomocą dwóch badań genetycznych, NGS i MLPA, wykryto u chorych zarówno warianty pojedynczego nukleotydu, jak i duże delecje. U większości chorych występowały warianty genu GCK (11/22) i (nieco rzadziej) genu HNF1B (5/22). Pozostałe warianty dotyczyły genów NEUROD1 i HNF1A Zidentyfikowano jeden nowy wariant w genie GCK: c.596T>C, p.Val199Ala. Zastosowane badania genetyczne pozwoliły wykluczyć cukrzycę MODY u dwóch chorych i wykazały warianty w innych genach prawdopodobnie związane z fenotypem klinicznym pacjentów. Wnioski: W badanej grupie chorych z cukrzycą MODY większość wariantów wykryto w genie GCK. Warianty występowały również w genach HNF1B, NEUROD1 i HNF1A. Połączenie badań genetycznych NGS i MLPA umożliwia kompleksową analizę u chorych z podejrzeniem cukrzycy MODY i jest skuteczną metodą w diagnostyce różnicowej podtypów cukrzycy MODY. (Endokrynol Pol 2019; 70 (1): 28-36)

Słowa kluczowe: MODY; NGS; MLPA; rozpoznanie różnicowe

\section{Introduction}

Maturity onset diabetes of the young (MODY) is a rare, monogenic type of diabetes that results from dysfunc- tion of pancreatic $\beta$-cells. It is characterised by an onset of hyperglycaemia before 25 years of age, autosomal dominant inheritance, and some forms are insulin independent upon diagnosis. MODY is found in $1-2 \%$ of 
all patients with diabetes. Due to overlapping clinical features with the common types of diabetes, type 1 and type 2, MODY could be misdiagnosed [1-3].

MODY arises from changes in single genes important for function, regulation and development of $\beta$-cells, glucose sensing or interaction with insulin [4]. Until now genetic variants of 13 genes have been associated with MODY. The most affected MODY genes are HNF1A, GCK, and HNF4A followed by HNF1B $[1,4]$. Each gene manifests a distinct clinical subtype. GCK-MODY subtype is unique because usually it does not require therapy and is not associated with the risk of microvascular complications [5]. In the case of HNF1A/4A-MODY subtypes, low doses of sulphonylurea provide better glycaemic control than treatment with insulin [6]. Renal impairment is a dominant clinical feature for HNF1B-MODY subtype, where insulin therapy is usually required $[7,8]$.

Distinguishing MODY diabetes from type 1 and type 2 diabetes, as well as determining the exact MODY subtype, has a great therapeutic and prognostic value for the patients. Patients with undiagnosed MODY diabetes are treated as type 1 or type 2 diabetes [9]. Consequently, they may receive unnecessary therapy or have difficulties in achieving a good glycaemic control $[6,9]$. The clinical criteria, according to which MODY patients are recognised or distinguished from other diabetic patients, are not sufficiently sensitive and are overlooked in half of MODY cases [3]. Genetic testing can determine if a patient's diabetes has a genetic cause, but it can also provide a correct sub-classification of MODY patients and the best management option [10].

Here we aimed to genetically characterise clinically suspected MODY patients, evaluate the relative frequency of MODY subtypes and to examine the nature of variants in MODY genes of Serbian paediatric patients. We used two different methods to analyse genes relevant for MODY: next-generation sequencing (NGS) and MLPA (multiplex ligation-dependent probe amplification) assay. This comprehensive approach for detection of both single nucleotide variants and large deletion in MODY genes enables a successful differential diagnosis of MODY subtypes. Additionally, it provided the first steps for implementing genetic diagnosis of MODY in Serbia.

\section{Material and methods}

\section{Subjects and clinical characteristics}

Twenty-nine unrelated paediatric patients and 38 family members were included in this study. Patients were treated at the Children's University Hospital in Belgrade, Serbia. They all had atypical diabetes that
Table I. Clinical characteristics of patients included in the study

Tabela I. Charakterystyka kliniczna chorych włączonych do badania

\begin{tabular}{lc}
\hline Patients & $\mathbf{2 9}$ \\
\hline Male/female & $\mathbf{2 3 / 6}$ \\
\hline Diabetes & \\
\hline Age [years, M $\pm \mathrm{SD}$ (range)] & $15.76 \pm 3.96(8.0-25.0)$ \\
\hline Age at diagnosis & $12.57 \pm 3.74(7.0-20.0)$ \\
[years, M \pm SD (range)] & \\
\hline Fasting glucose level [mmol/] & $6.69 \pm 1.47$ \\
\hline HbA ${ }_{1 \mathrm{c}}(\%)$ & $6.12 \pm 0.84$ \\
\hline BMI $\left[\mathrm{kg} / \mathrm{m}^{2}\right]$ & $20.21 \pm 3.67$ \\
\hline Family history of diabetes [yes] & 21 \\
\hline Therapy & \\
\hline Yes [lnsulin/OHA] & $6(2 / 4)$ \\
\hline No* & 23 \\
\hline Other clinical features & 9 \\
\hline Renal malformations & \\
\hline
\end{tabular}

Clinical parameters are presented as mean $\pm \mathrm{SD} ; \mathrm{OHA}$ - oral hypoglycaemic agents; * patients without therapy or on diet management

did not fully satisfy criteria for diabetes type 1 or type 2 . They met the criteria for a clinical diagnosis of monogenic diabetes: hyperglycaemia detected before the age of 25 years, presence of diabetes in the family, with autosomal dominant mode of inheritance, and in most cases insulin independence upon diagnosis of diabetes. Some patients had additional renal abnormalities. Clinical characteristics of patients included in the study are presented in Table I.

The study was approved by the Ethics Committee of the Children's University Hospital, Belgrade and was performed in accordance with the ethical standards of the Declaration of Helsinki. Informed consent was obtained from all participants included in the study.

\section{DNA Extraction and next-generation sequencing}

The DNA was extracted from whole blood samples using a QIAamp DNA Blood Mini Kit (Qigen, Germany) following the manufacturer's protocol.

Sequencing of genes was performed using Illumina's TruSight One Sequencing Panel (Illumina, San Diego, CA) containing 4813 clinically relevant genes. This panel contains all reagents necessary for tagmentation, indexing, amplification, and enrichment of the samples (library preparation). Each step was carried out according to the manufacturer's instructions. The library was quantified on the Qubit 2.0 Fluorometer and sequenced on an Illumina MiSeq instrument (Illumina, San Diego, CA) using 150bp paired-end reads. The generated sequencing data were submitted for analysis if the data 
passed the acceptance criteria for analytical runs according to the manufacturer's instructions.

\section{Processing sequencing data}

Sequencing data were aligned to the hg19 genome within Variant Studio Software (Version 2.2, Illumina Inc.) and filtered under conditions of heterozygous and homozygous mutations and frequency below 5\%. The following genes were analysed: HNF4A, GCK, HNF1A, PDX1, HNF1B, NEUROD1, KLF11, CEL, $P A X 4, I N S, B L K, A B C C 8$, and KCNJ11. Variants reported by the software as deleterious, damaging/probably damaging, or without any prediction were further inspected. They were checked in literature and public databases: HGMD database (public version), Ensemble (https://www.ensembl.org/), ExAc (http:// exac.broadinstitute.org), dbSNP (http://www.ncbi. nlm.nih.gov/snp), and ClinVar (https://www.ncbi. nlm.nih.gov/clinvar/). Novel variants were evaluated in silico using online predicting algorithms: Mutation Taster (http://www.mutationtaster.org/), SIFT (http:// sift.jcvi.org/), and PolyPhen-2 (http://genetics.bwh. harvard.edu/pph2/). Additionally, variants were searched for in our population-specific TruSight One-derived variant database. Variants classified as tolerated or benign by the software were excluded from further analysis.

\section{Validation of pathogenic variants}

Variants recognised as pathogenic were validated by a standardised Sanger sequencing method (BigDye ${ }^{\circledR}$ Terminator v3.1 Cycle Sequencing Kit [Applied Biosystems ${ }^{\circledR}$ ]). Primers were designed for each variant using the Primer Blast online tool (www.ncbi.nlm.nih. gov/tools/primer-blast/). Primer sequences and PCR conditions are presented in Tables II and III.

Table II. Primers sequences and annealing temperatures for each PCR reaction

Tabela II. Sekwencje primerów i temperatura hybrydyzacji (annealing) każdej reakcji

\begin{tabular}{|c|c|c|c|c|c|}
\hline Gene & Exon & & Primer sequence $\left(5^{\prime}\right.$ to $\left.3^{\prime}\right)$ & PCR product (bp) & Annealing Temp. ${ }^{*}\left({ }^{\circ} \mathrm{C}\right)$ \\
\hline \multirow{14}{*}{ GCK } & \multirow{2}{*}{3} & $\mathrm{~F}$ & TAG TCC CTT GTG CCT TCC CT & \multirow{2}{*}{380} & \multirow{2}{*}{60} \\
\hline & & $\mathrm{R}$ & СTC ССС АСС ССТ GGT AGA CA & & \\
\hline & \multirow{2}{*}{4} & $\mathrm{~F}$ & CAT TCA GTG GCC AGG TGT TG & \multirow{2}{*}{320} & \multirow{2}{*}{59} \\
\hline & & $\mathrm{R}$ & GGG GGC TAC ATT TGA AGG CA & & \\
\hline & \multirow{2}{*}{5} & $\mathrm{~F}$ & GGG ACT CAG CCC TGC AGA AAT A & \multirow{2}{*}{380} & \multirow{2}{*}{60} \\
\hline & & $\mathrm{R}$ & TGG AAG CCA AGG AGA AAG GCA & & \\
\hline & \multirow{2}{*}{6} & $\mathrm{~F}$ & AGG GCA TCC TTC TCA ACT GG & \multirow{2}{*}{434} & \multirow{2}{*}{60} \\
\hline & & $\mathrm{R}$ & ACC AGG CTC TGC TCT GAC ATC & & \\
\hline & \multirow{2}{*}{7} & $\mathrm{~F}$ & TGA AGC AAC CCA GGT CTT CC & \multirow{2}{*}{506} & \multirow{2}{*}{60} \\
\hline & & $\mathrm{R}$ & GAG CAG AAG GGA TGG AGC TT & & \\
\hline & \multirow{2}{*}{8} & $\mathrm{~F}$ & TGA ACC AGC TGG GGG AGT G & \multirow{2}{*}{374} & \multirow{2}{*}{60} \\
\hline & & $\mathrm{R}$ & GAG ACC AAG TCT GCA GTG CC & & \\
\hline & \multirow{2}{*}{9} & $\mathrm{~F}$ & ATC GCC CCC АTT TCT CCA GAG & \multirow{2}{*}{489} & \multirow{2}{*}{58} \\
\hline & & $\mathrm{R}$ & ATC TTG GAG CTT GGG AAC CGC & & \\
\hline \multirow{6}{*}{ HNF1B } & \multirow{2}{*}{1} & $\mathrm{~F}$ & CGG GGA GTA ACA GGT GTC TG & \multirow{2}{*}{596} & \multirow{2}{*}{58} \\
\hline & & $\mathrm{R}$ & GGG ACT TCT CTG GTG GGA AAC & & \\
\hline & \multirow{2}{*}{2} & $\mathrm{~F}$ & ССТ САT GTC TAC ССС AAA GTT G & \multirow{2}{*}{484} & \multirow{2}{*}{58} \\
\hline & & $\mathrm{R}$ & GGC CAA ATC TAC TTG CCA CC & & \\
\hline & \multirow{2}{*}{4} & $\mathrm{~F}$ & TCT TCT СCT CGA GAG CCA CA & \multirow{2}{*}{576} & \multirow{2}{*}{59} \\
\hline & & $\mathrm{R}$ & AGA TCC GTG GCA AGA ACC AG & & \\
\hline \multirow{4}{*}{ HNF1A } & 1 & $\mathrm{~F}$ & GAG TTT GGT TTG TGT CTG CCG & 521 & $c 0$ \\
\hline & 1 & $\mathrm{R}$ & GGG GAC TCA ACT CAG AAG GG & 521 & bu \\
\hline & $A$ & $\mathrm{~F}$ & TGC TCA CCC AAT TCG ATT CTC T & $f^{-1}$ & $s 0$ \\
\hline & 4 & $\mathrm{R}$ & GCA TGA ATG GAA TGG AAC CAA ACT & 605 & 60 \\
\hline$A I E$ & 2 & $\mathrm{~F}$ & CGC AAG GTG GTG CCT TGC TAT TC & 506 & 60 \\
\hline NEURUDT & 2 & $\mathrm{R}$ & GCA GCG GTG CCT GAG AAG ATT G & 596 & bu \\
\hline
\end{tabular}

Primer sequences and PCR temperature profile for Sanger validation of detected variants. PCR reactions were performed using OIAGEN Hot Start Taq $®$ DNA polymerase kit (Germany) according to manufacturer's recommendations. 
Table III. Temperature profile for all reactions

Tabela III. Profil temperaturowy wszystkich reakcji

\begin{tabular}{lcc}
\hline Reaction & Temperaure & Time \\
\hline Initial denaturation & $95^{\circ} \mathrm{C}$ & $15 \mathrm{~min}$ \\
\hline Denaturation & $95^{\circ} \mathrm{C}$ & $30 \mathrm{~s}$ \\
\hline Annealing & ${ }^{*} \mathrm{C}$ & $30 \mathrm{~s}$ \\
\hline Extension & $72^{\circ} \mathrm{C}$ & $45-60 \mathrm{~s}$ \\
\hline Final extension & $72^{\circ} \mathrm{C}$ & $10 \mathrm{~min}$ \\
\hline
\end{tabular}

Multiplex ligation-dependent probe amplification SALSA P241-B MODY kit (MRC-Holland, Amsterdam, The Netherlands) for multiplex ligation-dependent probe amplification assay (MLPA) was used to detect genomic rearrangements in genes for most common subtypes of MODY diabetes: HNF4A, GCK, HNF1A, and HNF1B. MLPA was carried out using $120 \mathrm{ng}$ of genomic DNA according to the manufacturer's instruc- tions. Coffalyser ${ }^{\circledR}$ software was used for graphic and statistical analysis.

\section{Results}

In order to provide a genetic diagnosis for 29 clinically suspected MODY patients, two methods were used. Using the TruSight One panel for next-generation sequencing, all genes confidently likened to MODY diabetes were analysed. When there was a suspicion of a HNF1B-MODY phenotype MLPA assay was additionally used in order to identify large deletions as a potential cause of this subtype of MODY diabetes. MLPA assay was also used if no changes in MODY genes were found in patients by sequencing. By this approach we detected variants in MODY genes in 22 out of 29 patients $(75.9 \%)$. Detected variants are summarised in Table IV. Sanger sequencing was used to validate detected variants, and false positives were not detected.

Table IV. Variants in MODY genes identified by NGS and MLPA assay

Tabela IV. Warianty genów związanych z cukrzyca MODY wykryte za pomocą badań NGS i MLPA

\begin{tabular}{|c|c|c|c|c|c|c|c|c|}
\hline No. $P$. & NGS & MLPA & $\begin{array}{l}\text { MODY } \\
\text { gene }\end{array}$ & Exon & $\begin{array}{l}\text { Type of sequence } \\
\text { change }\end{array}$ & cDNA change & Protein change & References \\
\hline 1 & $\checkmark$ & & GCK & 3 & Missense & c. $214 \mathrm{G}>\mathrm{A}$ & p.Gly72Arg & {$[45,46]$} \\
\hline 1 & $\checkmark$ & & GCK & 4 & Missense & c. $446 \mathrm{C}>\mathrm{T}$ & p.Thr149lle & {$[16]$} \\
\hline 1 & $\checkmark$ & & GCK & 5 & Missense & c. $533 \mathrm{G}>\mathrm{A}$ & pGly178Glu & [47] \\
\hline 1 & $\checkmark$ & & GCK & 5 & Missense & c. $572 \mathrm{G}>\mathrm{A}$ & p.Arg191Gln & {$[18,48]$} \\
\hline 1 & $\checkmark$ & & GCK & 6 & Missense & c.596T $>C$ & p.Val199Ala & Novel \\
\hline 1 & $\checkmark$ & & GCK & 7 & Missense & c. $745 \mathrm{G}>\mathrm{C}$ & p.Gly249Arg & [49] \\
\hline 1 & $\checkmark$ & & GCK & 7 & Missense & c. $763 \mathrm{~A}>\mathrm{G}$ & p.Thr255Ala & [19] \\
\hline 1 & $\checkmark$ & & GCK & 7 & Missense & c. $781 \mathrm{G}>\mathrm{A}$ & p.Gly261Arg & {$[19,50-52]$} \\
\hline 1 & $\checkmark$ & & GCK & 7 & Missense & c. $812 \mathrm{~T}>\mathrm{C}$ & p.Leu271Pro & ClinVar database \\
\hline 1 & $\checkmark$ & & GCK & 8 & Missense & c. $908 \mathrm{G}>\mathrm{T}$ & p.Arg303Leu & [53] \\
\hline 1 & $\checkmark$ & & GCK & 9 & Missense & c. $1148 \mathrm{C}>\mathrm{T}$ & p.Ser383Leu & {$[45,54]$} \\
\hline 1 & $\checkmark$ & $\checkmark$ & HNF1A & 1 & Missense & c. $293 C>T$ & p.Ala98Val & {$[36,55]$} \\
\hline 1 & $\checkmark$ & & HNF1A & 4 & Insertion & c.872dupC & p.Pro291fs & {$[32,56-58]$} \\
\hline 1 & $\checkmark$ & & HNF1B & 1 & Missense & c. $182 \mathrm{~T}>\mathrm{G}$ & p.Val61Gly & [59] \\
\hline 1 & $\checkmark$ & $\checkmark$ & HNF1B & 2 & Deletion & c.477delT & p.Met160Terfs & [60] \\
\hline 1 & $\checkmark$ & & HNF1B & 4 & Missense & c. $1006 \mathrm{C}>\mathrm{G}$ & p.His336Asp & [61] \\
\hline 1 & - & $\checkmark$ & HNF1B & $1,2,3$ & Exon deletion & c.1-?_809+?del & p.Met1_Arg270del & [62] \\
\hline 1 & $\checkmark$ & $\checkmark$ & HNF1B & 3,4 & Exon deletion & c.545-?_1045+?del & p.Gln182_Ser384del & {$[62][63]$} \\
\hline 2 & $\checkmark$ & $\checkmark$ & NEUROD1 & 2 & Missense & c. $590 \mathrm{C}>\mathrm{A}$ & p.Pro197His & [43] \\
\hline 1 & $\checkmark$ & & NEUROD1 & 2 & Missense & c. $590 \mathrm{C}>\mathrm{A}$ & p.Pro197His (hom*) & \\
\hline 1 & $\checkmark$ & & NEUROD1 & 2 & Missense & c. $750 \mathrm{C}>\mathrm{A}$ & p.Ser250Arg & $\begin{array}{l}\text { ExAc, dbSNP } \\
\text { databases }{ }^{\#}\end{array}$ \\
\hline
\end{tabular}

Sequence information is based on GeneBank reference sequences GCK: NM 000162.3; HNF1A: NM 000454.5; HNF1B: NM 0004585.2; NEURD1: NM 002500.4;

\#variants were found only in sequencing databases; No.P. — number of patients; hom* — variant in homozygous state; NGS — DNA samples analysed by Next generation sequencing method and TruSight One Panel; MLPA — DNA samples analysed by Multiplex Ligation-dependent Probe Amplification using SALSA P241-B probemi 


\section{Variants in GCK gene}

In the GCK gene we detected 11 different variants, one in each of the patients. This presents $50 \%$ of all detected variants in different MODY genes in 22 patients. All variants in GCK gene were heterozygous missense variants dispersed in almost all exons. Most of them were found in exon 7. Variants were confirmed by Sanger sequencing in parents and in family members where samples were available.

One novel variant was found in the GCK gene p.Val199Ala (c.596T >C) in one patient. Levels of FBG and $\mathrm{HbA}_{1 \mathrm{c}}$ for this patient were $6.7 \mathrm{mmol} / \mathrm{l}$ and $6.2 \%$, respectively. The variant was confirmed by Sanger sequencing in the mother who had mild hyperglycaemia. Prediction algorithms reported a damaging effect of the amino acid substitution on protein function for the variant p.Val199Ala. This variant was searched for in ExAc and dbSNP databases as well as in our population-specific TruSight One variant database (in-house database) and was not found in either one.

\section{Variants in HNF1B gene}

Heterozygous alterations in HNF1B gene were observed in $5 / 22$ patients. Both nucleotide variants and large deletions were detected. All variants have been previously reported. The variant p.His336Asp was also found in our in-house database.

In this group, the average levels of FBG and $\mathrm{HbA1c}$ were almost normal, and body mass index was in the normal range. All patients except one (data unavailable) had renal abnormalities. Family history of diabetes was reported for three patients. One patient needed insulin therapy because of high blood glucose, two were on diet management, and two were without therapy.

\section{Variants in HNF1A gene}

Two heterozygous variants, one missense and one insertion (c.293C > T, p.Ala98Val, and c.GLy292ArgfsTer25, p.Pro291fs) were detected in HNF1A gene by NGS. The detected insertion was confirmed in other family members: mother and sister. The variant p.Ala98Val was detected in a patient who had kidney transplantation before the genetic test was performed. The patient was initially suspected to have a HNF1B-MODY phenotype, but no variants or large deletions were found in HNF1B gene. Variant p.Ala98Val was also detected in one sample of our in-house database.

\section{Variants in NEUROD1 gene}

In the remaining $4 / 22$ patients two different variants were found, p.Pro197His, and p. Ser250Arg. Variant p.Pro197His was detected in three unrelated patients, and in one of them this variant was found in a homozy- gous state. The variant was also present in four samples of our in-house database. The variant p.Ser250Arg was reported only as sequence data in ExAc and dbSNP databases, and no data on the effect of this variant on clinical features in patients were reported. The variant is predicted to be probably benign by all predicting algorithms. Among analysed patients, it was found in one patient with a BMI $=27.8 \mathrm{~kg} / \mathrm{m}^{2}$ and $\mathrm{FBG} / \mathrm{HbA}_{1 \mathrm{c}}$ level $6.0 \mathrm{mmol} / \mathrm{l} / 6.1 \%$ and without therapy. No other variants in MODY genes were found in this patient.

\section{Discussion}

In patients with diagnosed diabetes but with clinical features atypical for diabetes type 1 or type 2, other rare types of diabetes should be considered, MODY being one of them. In patients with clinical characteristics suggestive of MODY diabetes, a genetic test could confirm or disprove the presumed diagnosis.

Next-generation sequencing technologies present an adequate method when there are larger numbers of genes to be analysed, as in the case of MODY diabetes $[11,12]$. Here, using the TruSight One panel comprising of 4813 genes, we have created a "virtual" gene panel of 13 genes that were associated with MODY diabetes and screened patients with a suspected diagnosis of MODY diabetes. [13]. Additionally, introduction of the MLPA assay made it possible to detect large deletion in most common MODY genes in patients with specific phenotypes. This primarily refers to HNF1B-MODY subtype, where whole or partial deletions of the HNF1B gene were reported in half of all cases, while for other MODY types they are very rare $[14,15]$.

A change in the MODY gene was found in 22/29 patients $(75 \%)$. Twenty different variants were found in common MODY genes, GCK, HNF1A, and HNF1B, and in NEUROD1 gene. The dominant subtype in our group was GCK-MODY (50\%), followed by HNF1B-MODY $(22.7 \%)$.

GCK-MODY is caused by at least 600 different variants that are distributed across the gene [16]. In Italy, the Czech Republic, and Spain, where paediatric patients are routinely tested for blood glucose levels, GCK-MODY is more frequently detected than other types of MODY [17-19]. In our group, 11 patients carried a different variant in the GCK gene, of which 10 had been previously reported. Most patients carrying a variant in the GCK gene are asymptomatic and their mild hyperglycaemia is incidentally detected $[17,20]$. Patients in our GCK group developed diabetes in early adolescence, at around 11 years of age. Their clinical phenotype corresponds to the phenotype of previously described patients with variants in GCK gene [20-22]. If not genetically confirmed, GCK-MODY diabetes can 
be misdiagnosed and may be treated with unnecessary glucose lowering medications [21-23]. Confirmation of having GCK diabetes brings a relief to patients by knowing that their diabetes will not progress during life, and that they are at very low risk of developing microvascular complications [5, 16, 21, 23]. Also, awareness of having GCK-MODY diabetes may be important for women when planning a family [21]. During pregnancy, due to the risk of foetal macrosomia in unaffected babies, mothers may be treated with insulin to avoid possible complications [21, 24].

We have identified one novel variant, p.Val199Ala (c.596T>C), in the GCK gene. Based on the in silico prediction algorithms, SIFT, PolyPhen-2, and Mutation taster, the variant, p.Val199Ala (c.596T >C) is considered likely to be pathogenic. Additional facts support the in silico prediction: (I) low frequency of this variant because it was not found in the population databases ExAc and dbSNP nor in our population-specific TruSight One variant database; (II) the patient's phenotype matches the phenotype of GCK-MODY diabetes; (III) the variant confirmed in the mother with mild hyperglycaemia was inherited in an autosomal dominant manner, which is consistent with the inheritance mode of the disease; and (IV) a different amino acid substitution on the same codon, p.Val199Leu, was previously reported in GCK-MODY patients [16].

Alterations in the HNF1B gene were found in $5 / 22$ patients. Single nucleotide variants as well as whole exon deletions were detected, which confirms the necessity of applying two methods when there is a suspicion of an HNF1B-MODY phenotype [25]. Patients may present with similar clinical features regardless of whether they carry a large deletion or single nucleotide variation in the HNF1B gene $[25,26]$.

Family history of diabetes and renal anomalies were observed in our patients. The average glucose levels were close to normal. This scenario, that renal malformations can occur prior to diabetes, has already been observed, especially in young patients, such as the ones in our HNF1B group, with an average age at diagnosis of 10 years $[8,15]$. Results from a systematic review have reported that while renal malformations were observed in almost all HNF1B carriers under 25 years old, only $21 \%$ of them developed diabetes. These patients should be monitored for blood glucose levels because they are at high risk of developing diabetes later in life [27]. It is possible for $H N F 1 B$ variant carriers to be free from insulin therapy or only use insulin sensitisers, as long as beta-cell function is preserved [28].

Patients with kidney malformations are candidates for the analysis of the HNF1B gene [29]. In our two patients with kidney malformations no changes in the HNF1B gene were found by sequencing or by MLPA assay. By using the TruSight One panel we were able to expand the list of analysed genes for these two patients. This enabled us to exclude HNF1B-MODY diabetes and to explore other genes that could be associated with the phenotype of these patients. A homozygous variant in BB1 gene (NM_024649.4: c.951+1G>A) responsible for Bradet-Biedl syndrome [30] was detected in one patient, while in the other patient two heterozygous variants in PKHD1 gene (NM_138694.3: c. 2414C > T, p.Pro805Leu and c.9530T > C p.Ile3177Thr) were found. These $P K H D 1$ gene variants are responsible for the autosomal recessive polycystic kidney disease (ARPKD) [31]. Variants in both genes have been previously reported and associated with the related diseases $[30,31]$.

HNF1A-MODY is considered to be the most frequent type of MODY diabetes in the Netherlands and the United Kingdom [9]. According to a large study comprising more than 2000 probands with diagnosed diabetes, half of the detected variants were found in the HNF1A gene [7]. In our group we found two patients with variants in the HNF1A gene. The low number of these patients may be because of the difficulty recognising them, which leaves them misdiagnosed. HNF1A-MODY is usually misdiagnosed with diabetes type 1 [6, 32-34]. Additional tests for IA2 and GAD antibodies, or highly sensitive C-reactive protein (hsCRP), could help differentiate HNF1A-MODY from type 1 diabetes, but are not routinely performed [6,33]. For these patients, the right diagnosis is crucial because it alters therapy. HNF1A variant carriers should be switched from insulin injections to oral sulphonylurea tablets because they are very sensitive to low doses of sulphonylurea. It is the first choice of therapy because it provides a better glycaemic control and reduces the risk of hypoglycaemia compared with insulin treatment [6].

One of the detected variants in the HNF1A gene was the most common variant, p.Pro291fs, present in $25 \%$ of all HNF1A variant carriers [20]. The other variant, p.Ala98Val, was reported previously and was not associated with monogenic diabetes [35,36]. The striking clinical feature of the patient was that he had kidney transplantation. It has been previously reported that variants in the HNF1A gene may produce a phenotype with renal abnormalities, but very rarely [37]. Without functional studies or clinical presentation of other patients carrying this variant, it is difficult to evaluate whether this variant in the HNF1A gene was associated with the renal phenotype and/or monogenic diabetes, or it was a coincidental finding.

Variants in the NEUROD1 gene associated with monogenic diabetes are very rare and have been reported in few families. Carriers of reported variants had diverse phenotypes. For most of them a higher 
body mass index and later onset of diabetes was a common feature [38-42]. We detected two variants in the NEUROD1 gene: p.Pro197His and p.Ser250Arg. The first variant, p.Pro197His, was detected in three patients both in homozygous and heterozygous state, but the state of zygosity of the allele did not manifest a difference in the clinical phenotype. Functional studies showed that p.Pro197His variant does not alter the transcription of the insulin gene and therefore its role in the pathogenesis of diabetes was excluded [43]. Variant p.Ser250Arg was reported only as sequence data and was predicted to be benign. Here it was detected in a slightly overweight patient with elevated glycaemia and without therapy. There are some indications that obesity may be the factor that triggers the development of diabetes in NEUROD1 variant carriers [40]. Given that detected changes were not likely to be associated with diabetes, and that disease-causing variants were not found in other MODY genes, the exact cause of diabetes in these patients remains unknown.

This type of study was the first one conducted in our country, and it set the roots for implementing genetic testing of MODY diabetes into routine genetic practice. Accurate diagnosis will lead to improvement of patient care and management. Benefits of implementing this methodology can be seen on different levels. By sequencing all genes simultaneously, the rate of molecular confirmation of the diagnosis is higher than when requesting an analysis for a specific gene. The genetic test for a specific MODY gene is requested according to the observed phenotype and available clinical characteristics in patients $[10,44]$. Due to clinical variability, the selection of an appropriate gene to test can be challenging, and if the presumption is wrong, it could lead to a false negative result. The consequence is not only the failure to identify the possible causative disease variant, but also additional costs for further analysis. As the cost of NGS sequencing continues to drop, it will become more available. This type of analysis does not only provide information for 13 MODY genes selected for the study, but for the entire clinical exome per patient, where in some cases it could be used to extend the initial gene list without further costs.

\section{Conclusions}

This study is the first to report molecular the genetic basis of MODY of Serbian paediatric patients. The results of this study provided two major conclusions. First, there is a need for a genetic test when clinical parameters indicate GCK-MODY diabetes. Conformation of this type of diabetes will provide appropriate care to patients and reduce healthcare costs due to unnecessary medications. Secondly, poor recognition of
HNF1A-MODY indicates the necessity for additional non-genetic testing prior to genetic, in order to better distinguish from other patients with common types of diabetes.

Describing more patients and providing clinical characteristic will contribute to our present knowledge of MODY diabetes. Implementation of genetic testing in clinical practice will improve the care of MODY patients because it will be based on an individualised approach, save costs of unnecessary therapy, and offer genetic counselling for family members.

\section{Acknowledgements}

This work has been funded by grants from the Ministry of Education, Science, and Technological Development, Serbia (III 41004) given to S.P.

\section{Conflict of interest}

The authors have nothing to declare.

\section{Authors contribution}

J.K. - experimental: molecular analysis, data analysis, preparation of the manuscript; V.Z. - samples, clinical data and management of patients, critical review of the manuscript; S.S. - samples, clinical data and management of patients; M.J. — samples, clinical data; M.A. - experimental: molecular analysis, data analysis; S.P. - design of the study, coordination of the research, preparation of the manuscript; M.U. - design of the study, coordination of the research, preparation of the manuscript.

\section{References}

1. Lachance $\mathrm{CH}$. Practical Aspects of Monogenic Diabetes: A Clinical Point of View. Can J Diabetes. 2016; 40(5): 368-375, doi: 10.1016/j. jcjd.2015.11.004, indexed in Pubmed: 26897468.

2. Colclough K, Saint-Martin C, Timsit J, et al. Clinical utility gene card for: Maturity-onset diabetes of the young. Eur J Hum Genet. 2014; 22(9), doi: 10.1038/ejhg.2014.14, indexed in Pubmed: 24518839.

3. Shields B, Colclough K. Towards a systematic nationwide screening strategy for MODY. Diabetologia. 2017; 60(4): 609-612, doi: 10.1007/s00125-017-4213-7, indexed in Pubmed: 28132100.

4. Naylor R, Philipson LH. Who should have genetic testing for maturity-onset diabetes of the young? Clin Endocrinol (Oxf). 2011; 75(4): 422-426, doi: 10.1111/j.1365-2265.2011.04049.x, indexed in Pubmed: 21521318.

5. Steele AM, Shields BM, Wensley KJ, et al. Prevalence of vascular complications among patients with glucokinase mutations and prolonged, mild hyperglycemia. JAMA. 2014; 311(3): 279-286, doi: 10.1001/jama.2013.283980, indexed in Pubmed: 24430320.

6. Shepherd M, Miles S, Jones J, et al. Differential diagnosis: Identifying people with monogenic diabetes. Journal of Diabetes Nursing. 2010; 14: 342-347.

7. Shields BM, Hicks S, Shepherd MH, et al. Maturity-onset diabetes of the young (MODY): how many cases are we missing? Diabetologia. 2010; 53(12): 2504-2508, doi: 10.1007/s00125-010-1799-4, indexed in Pubmed: 20499044

8. Bingham C, Hattersley AT. Renal cysts and diabetes syndrome resulting from mutations in hepatocyte nuclear factor-1beta. Nephrol Dial Transplant. 2004; 19(11): 2703-2708, doi: 10.1093/ndt/gfh348, indexed in Pubmed: 15496559.

9. Kleinberger JW, Pollin TI. Undiagnosed MODY: Time for Action. Curr Diab Rep. 2015; 15(12): 110, doi: 10.1007/s11892-015-0681-7, indexed in Pubmed: 26458381. 
10. Nyunt $\mathrm{O}$, Wu JY, McGown IN, et al. Investigating maturity onset diabetes of the young. Clin Biochem Rev. 2009; 30(2): 67-74, indexed in Pubmed: 19565026.

11. Gao R, Liu Y, Gjesing AP, et al. Evaluation of a target region capture sequencing platform using monogenic diabetes as a study-model. BMC Genet. 2014; 15: 13, doi: 10.1186/1471-2156-15-13, indexed in Pubmed: 24476040.

12. Johansson S, Irgens $\mathrm{H}$, Chudasama KK, et al. Exome sequencing and genetic testing for MODY. PLoS One. 2012; 7(5): e38050, doi: 10.1371/journal.pone.0038050, indexed in Pubmed: 22662265.

13. Ellard S, Lango Allen H, De Franco E, et al. Improved genetic testing for monogenic diabetes using targeted next-generation sequencing. Diabetologia. 2013; 56(9): 1958-1963, doi: 10.1007/s00125-013-2962-5, indexed in Pubmed: 23771172.

14. Ellard S, Thomas K, Edghill EL, et al. Partial and whole gene deletion mutations of the GCK and HNF1A genes in maturity-onset diabetes of the young. Diabetologia. 2007; 50(11): 2313-2317, doi: 10.1007/s00125-007-0798-6, indexed in Pubmed: 17828387.

15. Edghill EL, Stals K, Oram RA, et al. HNF1B deletions in patients with young-onset diabetes but no known renal disease. Diabet Med. 2013; 30(1): 114-117, doi: 10.1111/j.1464-5491.2012.03709.x, indexed in Pubmed: 22587559 .

16. Osbak KK, Colclough K, Saint-Martin C, et al. Update on mutations in glucokinase (GCK), which cause maturity-onset diabetes of the young permanent neonatal diabetes, and hyperinsulinemic hypoglycemia. Hum Mutat. 2009; 30(11): 1512-1526, doi: 10.1002/humu.21110, indexed in Pubmed: 19790256.

17. Lorini R, Klersy C, d'Annunzio G, et al. Italian Society of Pediatric Endocrinology and Diabetology (ISPED) Study Group. Maturity-onset diabetes of the young in children with incidental hyperglycemia: a multicenter Italian study of 172 families. Diabetes Care. 2009; 32(10): 1864-1866, doi: 10.2337/dc08-2018, indexed in Pubmed: 19564454

18. Pruhova S, Dusatkova P, Sumnik Z, et al. Glucokinase diabetes in 103 families from a country-based study in the Czech Republic: geographically restricted distribution of two prevalent GCK mutations. Pediatr Diabetes. 2010; 11(8): 529-535, doi: 10.1111/j.1399-5448.2010.00646.x indexed in Pubmed: 20337973.

19. Estalella I, Rica I, Perez de Nanclares G, et al. Spanish MODY Group. Mutations in GCK and HNF-1alpha explain the majority of cases with clinica diagnosis of MODY in Spain. Clin Endocrinol (Oxf). 2007; 67(4): 538-546, doi: 10.1111/j.1365-2265.2007.02921.x, indexed in Pubmed: 17573900.

20. Hattersley AT. Maturity-onset diabetes of the young: clinical heterogeneity explained by genetic heterogeneity. Diabet Med. 1998; 15(1): 15-24 doi: 10.1002/(SICI)1096-9136(199801)15:1<15::AID-DIA562>3.0.CO;2-M , indexed in Pubmed: 9472859

21. Carmody D, Naylor RN, Bell CD, et al. GCK-MODY in the US National Monogenic Diabetes Registry: frequently misdiagnosed and unnecessarily treated. Acta Diabetol. 2016; 53(5): 703-708, doi: 10.1007/s00592-016-0859-8, indexed in Pubmed: 27106716.

22. Murphy R, Ellard S, Hattersley AT. Clinical implications of a molecular genetic classification of monogenic beta-cell diabetes. Nat Clin Pract Endocrinol Metab. 2008; 4(4): 200-213, doi: 10.1038/ncpendmet0778, indexed in Pubmed: 18301398.

23. Bansal V, Gassenhuber J, Phillips T, et al. Spectrum of mutations in monogenic diabetes genes identified from high-throughput DNA sequencing of 6888 individuals. BMC Med. 2017; 15(1): 213, doi 10.1186/s12916-017-0977-3, indexed in Pubmed: 29207974

24. Murphy R. Monogenic diabetes and pregnancy. Obstet Med. 2015; 8(3): 114-120, doi: 10.1177/1753495X15590713, indexed in Pubmed: 27512465.

25. Bellanné-Chantelot C, Clauin S, Chauveau D, et al. Large genomic rearrangements in the hepatocyte nuclear factor-1beta (TCF2) gene are the most frequent cause of maturity-onset diabetes of the young type 5. Diabetes. 2005; 54(11): 3126 3132, indexed in Pubmed: 16249435.

26. Ulinski T, Lescure S, Beaufils S, et al. Renal phenotypes related to hepatocyte nuclear factor-1beta (TCF2) mutations in a pediatric cohort. J Am Soc Nephrol. 2006; 17(2): 497-503, doi: 10.1681/ASN.2005101040, indexed in Pubmed: 16371430.

27. Chen $\mathrm{YZ}$, Gao Q, Zhao XZ, et al. Systematic review of TCF2 anomalies in renal cysts and diabetes syndrome/maturity onset diabetes of the young type 5. Chin Med J (Engl). 2010; 123(22): 3326-3333, indexed in Pubmed: 21163139.

28. Thirumalai A, Holing E, Brown Z, et al. A case of hepatocyte nuclear factor- $1 \beta$ (TCF2) maturity onset diabetes of the young misdiagnosed as type 1 diabetes and treated unnecessarily with insulin. J Diabetes. 2013; 5(4) 462-464, doi: 10.1111/1753-0407.12043, indexed in Pubmed: 23480312.

29. Raaijmakers A, Corveleyn A, Devriendt K, et al. Criteria for HNF1B analysis in patients with congenital abnormalities of kidney and urinary tract. Nephrol Dial Transplant. 2015; 30(5): 835-842, doi: 10.1093/ndt/gfu370, indexed in Pubmed: 25500806.

30. Fauser S, Munz M, Besch D. Further support for digenic inheritance in Bardet-Biedl syndrome. J Med Genet. 2003; 40(8): e104, indexed in Pubmed: 12920096.
31. Losekoot M, Haarloo C, Ruivenkamp C, et al. Analysis of missense variants in the PKHD1-gene in patients with autosomal recessive polycystic kidney disease (ARPKD). Hum Genet. 2005; 118(2): 185-206, doi: 10.1007/s00439-005-0027-7, indexed in Pubmed: 16133180.

32. Ellard S, Colclough K. Mutations in the genes encoding the transcription factors hepatocyte nuclear factor 1 alpha (HNF1A) and 4 alpha (HNF4A) in maturity-onset diabetes of the young. Hum Mutat. 2006; 27(9): 854-869, doi: 10.1002/humu.20357, indexed in Pubmed: 16917892.

33. Owen KR, Thanabalasingham G, James TJ, et al. Assessment of high-sensitivity $\mathrm{C}$-reactive protein levels as diagnostic discriminator of maturity-onset diabetes of the young due to HNF1A mutations. Diabetes Care. 2010; 33(9): 1919-1924, doi: 10.2337/dc10-0288, indexed in Pubmed: 20724646.

34. Bellanné-Chantelot C, Lévy DI, Carette C, et al. French Monogenic Diabetes Study Group. Clinical characteristics and diagnostic criteria of maturity-onset diabetes of the young (MODY) due to molecular anomalies of the HNF1A gene. J Clin Endocrinol Metab. 2011; 96(8): E1346-E1351, doi: 10.1210/jc.2011-0268, indexed in Pubmed: 21677039.

35. Pruhova S, Ek J, Lebl J, et al. Genetic epidemiology of MODY in the Czech republic: new mutations in the MODY genes HNF-4alpha, GCK and HNF-1alpha. Diabetologia. 2003; 46(2): 291-295, doi: 10.1007/s00125-002-1010-7, indexed in Pubmed: 12627330.

36. Anuradha S, Radha V, Deepa R, et al. A prevalent amino acid polymorphism at codon 98 (Ala98Val) of the hepatocyte nuclear factor-1alpha is associated with maturity-onset diabetes of the young and younger age at onset of type 2 diabetes in Asian Indians. Diabetes Care. 2005; 28(10): 2430-2435, indexed in Pubmed: 16186275.

37. Malecki MT, Skupien J, Gorczynska-Kosiorz S, et al. Renal malformation may be linked to mutations in the hepatocyte nuclear factor-1alpha (MODY3) gene. Diabetes Care. 2005; 28(11): 2774-2776, indexed in Pubmed: 16249556

38. Malecki MT, Jhala US, Antonellis A, et al. Mutations in NEUROD1 are associated with the development of type 2 diabetes mellitus. Nat Genet. 1999; 23(3): 323-328, doi: 10.1038/15500, indexed in Pubmed: 10545951.

39. Kristinsson SY, Thorolfsdottir ET, Talseth B, et al. MODY in Iceland is associated with mutations in HNF-1alpha and a novel mutation in NeuroD1. Diabetologia. 2001; 44(11): 2098-2103, doi: 10.1007/s001250100016, indexed in Pubmed: 11719843.

40. Gonsorcíková L, Průhová S, Cinek O, et al. Autosomal inheritance of diabetes in two families characterized by obesity and a novel H241Q mutation in NEUROD1. Pediatr Diabetes. 2008; 9(4 Pt 2): 367-372, doi: 10.1111/j.1399-5448.2008.00379.x, indexed in Pubmed: 18331410.

41. Szopa M, Ludwig-Galezowska AH, Radkowski P, et al. A family with the Arg103Pro mutation in the NEUROD1 gene detected by next-generation sequencing - Clinical characteristics of mutation carriers. Eur J Med Genet. 2016; 59(2): 75-79, doi: 10.1016/j.ejmg.2016.01.002, indexed in Pubmed: 26773576.

42. Liu L, Furuta $\mathrm{H}$, Minami A, et al. A novel mutation, Ser159Pro in the NeuroD1/BETA2 gene contributes to the development of diabetes in a Chinese potential MODY family. Mol Cell Biochem. 2007; 303(1-2): 115-120, doi: 10.1007/s11010-007-9463-0, indexed in Pubmed: 17440689.

43. Hansen L, Jensen JN, Urioste S, et al. NeuroD/BETA2 gene variability and diabetes: no associations to late-onset type 2 diabetes but an A45 allele may represent a susceptibility marker for type 1 diabetes among Danes. Danish Study Group of Diabetes in Childhood, and the Danish IDDM Epidemiology and Genetics Group. Diabetes. 2000; 49(5): 876-878, indexed in Pubmed: 10905500

44. Thomas ERa, Brackenridge A, Kidd J, et al. Diagnosis of monogenic diabetes: 10-Year experience in a large multi-ethnic diabetes center. J Diabetes Investig. 2016; 7(3): 332-337, doi: 10.1111/jdi.12432, indexed in Pubmed: 27330718.

45. Bonfig W, Hermanns S, Warncke K, et al. GCK-MODY (MODY 2) Caused by a Novel p.Phe330Ser Mutation. ISRN Pediatr. 2011; 2011: 676549, doi: 10.5402/2011/676549, indexed in Pubmed: 22389783.

46. Cullen KS, Matschinsky FM, Agius L, et al. Susceptibility of glucokinase-MODY mutants to inactivation by oxidative stress in pancreatic $\beta$-cells. Diabetes. 2011; 60(12): 3175-3185, doi: 10.2337/db11-0423, indexed in Pubmed: 22028181

47. Johansen A, Ek J, Mortensen HB, et al. Half of clinically defined maturity-onset diabetes of the young patients in Denmark do not have mutations in HNF4A, GCK, and TCF1. J Clin Endocrinol Metab. 2005; 90(8): 4607-4614, doi: 10.1210/jc.2005-0196, indexed in Pubmed: 15928245 .

48. Codner E, Rocha A, Deng L, et al. Mild fasting hyperglycemia in children: high rate of glucokinase mutations and some risk of developing type 1 diabetes mellitus. Pediatr Diabetes. 2009; 10(6): 382-388, doi: 10.1111/j.1 399-5448.2009.00499.x, indexed in Pubmed: 19309449.

49. Borowiec M, Antosik K, Fendler W, et al. Novel glucokinase mutations in patients with monogenic diabetes - clinical outline of GCK-MD and potential for founder effect in Slavic population. Clin Genet. 2012; 81(3): 278-283, doi: 10.1111/j.1399-0004.2011.01656.x, indexed in Pubmed: 21348868 
50. Sakura H, Eto K, Kadowaki H, et al. Structure of the human glucokinase gene and identification of a missense mutation in a Japanese patient with early-onset non-insulin-dependent diabetes mellitus. J Clin Endocrinol Metab. 1992; 75(6): 1571-1573, doi: 10.1210/jcem.75.6.1464666, indexed in Pubmed: 1464666.

51. Weinert LS, Silveiro SP, Giuffrida FMA, et al. Three unreported glucokinase (GCK) missense mutations detected in the screening of thirty-two Brazilian kindreds for GCK and HNF1A-MODY. Diabetes Res Clin Pract. 2014; 106(2): e44-e48, doi: 10.1016/j.diabres.2014.08.006, indexed in Pubmed: 25174781.

52. Beer NL, Osbak KK, van de Bunt M, et al. Insights into the pathogenicity of rare missense GCK variants from the identification and functional characterization of compound heterozygous and double mutations inherited in cis. Diabetes Care. 2012; 35(7): 1482-1484, doi: 10.2337/dc11-2420, indexed in Pubmed: 22611063.

53. Papadimitriou DT, Willems PJ, Bothou C, et al. A novel heterozygous mutation in the glucokinase gene is responsible for an early-onset mild form of maturity-onset diabetes of the young, type 2. Diabetes Metab. 2015; 41(4): 342-343, doi: 10.1016/j.diabet.2015.03.009, indexed in Pubmed: 25921421

54. Gloyn AL. Glucokinase (GCK) mutations in hyper- and hypoglycemia: maturity-onset diabetes of the young, permanent neonatal diabetes, and hyperinsulinemia of infancy. Hum Mutat. 2003; 22(5): 353-362, doi: 10.1002/humu.10277, indexed in Pubmed: 14517946.

55. Shakya P, Aryal S, Aryal R, et al. Occurrence of amino acid mutation (Ala98Val) of HNF1 $\alpha$ in association with type II diabetes. J Nepal Health Res Counc. 2014; 12(27): 116-118, indexed in Pubmed: 25575005.
56. Yamagata K, Nammo T, Moriwaki M, et al. Mutation P291fsinsC in the transcription factor hepatocyte nuclear factor-1alpha is dominant negative. Diabetes. 1998; 47(8): 1231-1235, indexed in Pubmed: 9703322.

57. Yamada S, Nishigori H, Onda H, et al. Identification of mutations in the hepatocyte nuclear factor (HNF)-1 alpha gene in Japanese subjects with IDDM. Diabetes. 1997; 46(10): 1643-1647, indexed in Pubmed: 9313763.

58. Wang H, Antinozzi PA, Hagenfeldt KA, et al. Molecular targets of a human HNF1 alpha mutation responsible for pancreatic beta-cell dysfunction. EMBO J. 2000; 19(16): 4257-4264, doi: 10.1093/emboj/19.16.4257, indexed in Pubmed: 10944108.

59. Faguer S, Decramer S, Chassaing N, et al. Diagnosis, management, and prognosis of HNF1B nephropathy in adulthood. Kidney Int. 2011; 80(7): 768-776, doi: 10.1038/ki.2011.225, indexed in Pubmed: 21775974.

60. Bingham C, Bulman MP, Ellard S, et al. Mutations in the hepatocyte nuclear factor-1beta gene are associated with familial hypoplastic glomerulocystic kidney disease. Am J Hum Genet. 2001; 68(1): 219-224, doi: 10.1086/316945, indexed in Pubmed: 11085914.

61. Weber S, Moriniere V, Knüppel T, et al. Prevalence of mutations in renal developmental genes in children with renal hypodysplasia: results of the ESCAPE study. J Am Soc Nephrol. 2006; 17(10): 2864 2870, doi: 10.1681/ASN.2006030277, indexed in Pubmed: 16971658.

62. Yorifuji T, Fujimaru R, Hosokawa Y, et al. Comprehensive molecular analysis of Japanese patients with pediatric-onset MODY-type diabetes mellitus. Pediatr Diabetes. 2012; 13(1): 26-32, doi: 10.1111/j.1399-5448.2 011.00827.x, indexed in Pubmed: 22060211. 